\title{
Occurrence of adults and biological aspects of Geniates borelli Camerano (Coleoptera, Scarabaeidae, Rutelinae) in Aquidauana, MS, Brazil
}

\author{
Sergio Roberto Rodrigues ${ }^{1}$, Crislany Lima Barbosa ${ }^{2}$, Alfredo Raul Abot ${ }^{1} \&$ Sérgio Ide $^{3}$
}

\begin{abstract}
'Universidade Estadual de Mato Grosso do Sul, Rodovia Aquidauana/CERA km 12, 79200-000 Aquidauana-MS, Brasil. sergio@uems.br, arabot@uems.br ${ }^{2}$ Programa de Pós-Graduação em Entomologia Agrícola, Faculdade de Ciências Agrárias e Veterinárias, Universidade Estadual Paulista, Rodovia Prof. Dr. Donato Castellane, s/n, 14884-900 Jaboticabal-SP, Brasil. cry_entoagro@hotmail.com

${ }^{3}$ Centro de Pesquisa e Desenvolvimento de Sanidade Vegetal, Instituto Biológico, Av. Conselheiro Rodrigues Alves 1252, 04014-900 São Paulo-SP, Brasil.ide@biologico.sp.gov.br
\end{abstract}

\begin{abstract}
Occurrence of adults and biological aspects of Geniates borelli Camerano (Coleoptera, Scarabaeidae, Rutelinae) in Aquidauana, Mato Grosso do Sul, Brazil. Due to the importance of Geniates borelli Camerano as a pest in many crops, studies were developed at Universidade Estadual de Mato Grosso do Sul, Aquidauana campus, MS, Brazil. Adults were collected with a light trap from January 2006 to December 2007. 3,320 adults were collected, and the highest quantities were obtained in October 2006 and November 2007, with 1,548 and 802 adults recorded, respectively. Collected adults were kept in plastic containers with soil and Brachiaria decumbens seedlings for oviposition. 535 eggs measuring $2.30 \times 1.60 \mathrm{~mm}$ were obtained. As the embryonic development progressed, eggs increased in size to $3.00 \times 2.70 \mathrm{~mm}$, and this change occurred between 6 and 10 days after oviposition. The embryonic period lasted 17.9 days. The first, second, and third instars lasted 37.6, 49.7, and 74 days, respectively. The prepupal stage lasted 65.9 days and the pupal stage lasted an average of 18.5 days. The biological cycle is completed in 315.8 days, which characterizes the species as univoltine. The average longevity of females was 35.4 days and 28.5 days for males.
\end{abstract}

KEYWORDS. Biological cycle; Insecta; Scarabaeoidea; soil pest; white grub.

RESUMO. Ocorrência de adultos e aspectos biológicos de Geniates borelli Camerano (Coloptera, Scarabaeidae, Rutelinae) em Aquidauana, Mato Grosso do Sul, Brasil. Devido a importância de Geniates borelli Camerano como praga de culturas, foram desenvolvidos estudos na Universidade Estadual de Mato Grosso do Sul, no campus de Aquidauana, MS. Com o uso de armadilha luminosa realizou-se a coleta de adultos de janeiro de 2006 a dezembro de 2007. Foram coletados 3.320 adultos, e as maiores quantidades foram obtidas em outubro de 2006 e novembro de 2007, onde se registraram, respectivamente 1.548 e 802 adultos. Os adultos coletados foram mantidos em recipientes de plástico, contendo solo e mudas de Brachiaria decumbens, para que estes realizassem a oviposição. Foram obtidos 535 ovos com dimensões de 2,30 x 1,60 mm e com o desenvolvimento embrionário ocorre aumento de tamanho para $3,00 \times 2,70 \mathrm{~mm}$ e essa mudança do formato ocorreu entre o $6^{\circ}$ e $10^{\circ}$ dia após a oviposição. O período embrionário durou 17,9 dias, o primeiro, segundo e terceiro instar duraram 37,6, 49,7 e 74 dias, respectivamente. A pré-pupa durou 65,9 dias e a fase de pupa durou a média de 18,5 dias. O ciclo biológico completa-se em 315,8 dias, o que caracteriza a espécie como univoltina. A longevidade média das fêmeas foi de 35,4 dias e dos machos 28,5 dias.

PALAVRAS-CHAVE. Ciclo biológico; coró; Insecta; praga-de-solo; Scarabaeoidea.

In Brazil, some phytophagous Scarabaeidae species are related, causing damage in crops, which requires in many situations the use of control techniques to decrease the population density of these insects. Therefore, in addition to direct damages in crops, this group can cause increased in production costs. According to Morón (2004), there are in Brazil 1,008 species of soil-inhabiting Scarabaeidae (Pleurosticti), grouped in the subfamilies Melolonthinae, Rutelinae, Dynastinae, and Cetoniinae.

Studying the biology of this group of pests is a very complex undertaking, since their soil-inhabiting behavior and feeding on plant roots where they complete their cycle make observations and measurements are difficult to obtain. Therefore, information on aspects related to the biology of pest Scarabaeidae species is scarce.

With respect to the subfamily Melolonthinae in Brazil, there are known studies on the biological aspects of Phyllophaga triticophaga Morón \& Salvadori, 1998
(Salvadori \& Silva 2004), P. cuyabana (Moser, 1918) (Oliveira et al. 1996; Oliveira \& Garcia 2003), P. aff. capillata (Blanchard) (Oliveira et al. 2007), Liogenys fuscus Blanchard, 1850 (Rodrigues et al. 2008b), and L. suturalis Blanchard, 1851 (Santos \& Ávila 2009).

In the subfamily Dynastinae, biological studies have been conducted for Diloboderus abderus Sturm, 1826 (Silva \& Salvadori 2004), Cyclocephala forsteri Endrodi, 1963 (Santos \& Ávila 2007), Cyclocephala verticalis Burmeister, 1847 (Rodrigues et al. 2010a) and Aegopsis bolboceridus (Thomson, 1860) (Oliveira et al. 2008).

In the subfamily Rutelinae studies have been conducted only for Anomala testaceipennis Blanchard, 1856 and Leucothyreus dorsalis Blanchard, 1850 (Rodrigues et al. 2008a, 2010b). In studies on the phytophagous Scarabaeidae that occur in the region of Aquidauana, MS, adults of Geniates borelli Camerano, 1894 (Rutelinae, Geniatini) have been collected. Several species are listed in this tribe for Brazil; 
however, their biological aspects are unknown (Morón 2004). Therefore, this study aimed to investigate the population dynamics and biological aspects of this species.

\section{MATERIAL AND METHODS}

Geniates borelli adults were collected with a light trap at Universidade Estadual de Mato Grosso do Sul's experimental farm, in Aquidauana, MS. This trap was installed daily from January 2006 to December 2007 between pasture and agriculture areas, and was activated at 18:00 hours and withdrawn at 6:00 hours the next day. From October to December 2007, a few adults collected in the trap weekly were sexed and the females were dissected in the laboratory to count and analyze the eggs in the same way as performed by Crocker et al. (1999).

For the biology study, 158 adult pairs were formed and placed in plastic containers measuring $20 \times 30 \times 12 \mathrm{~cm}$ (depth), containing soil and seedlings of Brachiaria decumbens Stapf to allow mating, feeding, and oviposition. Each container was wrapped in voile fabric and received two insect pairs, so as to allow plant growth and restrain the adults. The containers were inspected weekly for the presence of eggs as well as to start the biology studies; this methodology was used by Rodrigues et al. (2010b).

After obtaining the eggs, they were placed in gerbox-type plastic boxes $(11 \times 11 \times 4 \mathrm{~cm})$; a layer of soil was placed in each box and a single egg was deposited onto the soil. The boxes containing eggs remained in an incubator $\left(26^{\circ} \mathrm{C} \pm 1\right.$ and a 12-hour photophase). When the embryonic development was completed and the larvae appeared, larvae were transferred individually to plastic containers $(500 \mathrm{~mL})$, containing soil and $B$. decumbens plants as food, and also remained in an incubator until the adult stage was reached.

Brachiaria decumbens plants in the plastic pots were replaced weekly with fresh seedlings for larval development. The head capsules of 50 larvae were measured at intervals of 3 to 4 days, as performed by Rodrigues et al. (2008a, b). In order to obtain the larval growth rate, the data were submitted to analysis according to Dyar's rule, as used by Parra \& Haddad (1989).

Pupae were formed and maintained in $500 \mathrm{~mL}$ plastic containers covered with voal fabric containing only soil until reach the emergence of adults. At the time insects reached the adult stage, a few pairs were maintained in plastic containers with soil and $B$. decumbens plants for daily observations on longevity and oviposition.

\section{RESULTS AND DISCUSSION}

In the first year 2,056 G. borelli adults were collected by light trap. From January to April only a small number of adults were caught and from May to August no insects were caught (Fig. 1). From September on, 194 adults (9.4\%) were collected, while 1,548 adults $(75.3 \%)$ were obtained in October, characterizing it as the month with the highest occurrence.
In November 176 individuals $(8.6 \%)$ were found, while in December adults were still found in the field, but in small numbers (Fig. 1).

In the second year 1,264 adults were collected. Eight specimens were found from January to February and from March to September no more adults were found in the field. In October 141 specimens (11.2\%) were collected and 802 adults $(63.4 \%)$ were recorded in November, which was considered the month with the highest occurrence; 313 adults $(24.8 \%)$ were collected in December (Fig. 1).

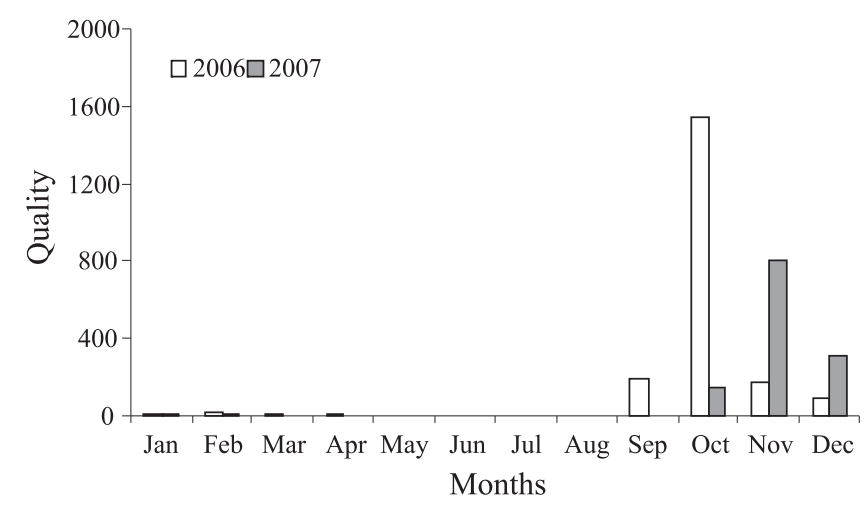

Fig. 1. Number of adults from Geniates borelli Camerano collected with light trap from January 2006 to December 2007, in Aquidauana, MS, Brazil.

Information on the occurrence of Geniates species in the country is scarce. However, in the municipality of Santa Bárbara, MG according to Freitas et al. (2002) three adults of Geniates laevis Camerano, 1878 were collected in October 1993 with a light trap, while one adult was captured in a Eucalyptus grandis stand in March 1994.

In the present study 3,320 individuals were captured in both years, of which 2,929 (88.2\%) were females and 391 $(11.8 \%)$ were males, giving a 9:1 sex ratio. According to Gómez et al. (1999) a 3:1 sex ratio was obtained for Anomala atomogramma Bates, 1888 (Scarabaeidae, Rutelinae).

With regard to dissected G. borelli females, developing eggs were observed about 14 days after the beginning of swarming in 2007; since females began swarming by the end of October, no developing eggs were found in that month. In November was found an average of 17.5 eggs per female (1$34)(n=50)$, while an average of 17.4 eggs $(1-29)(n=50)$ was found in December.

According to Rodrigues et al. (2008b), in the second year of collections of L. fuscus, females with eggs started to occur about 20 days after the beginning of swarming. Accordingly, an average of nine eggs per female was found in September, 15.6 in October, 12.6 in November, and six in December. While dissecting A. testaceipennis females, Rodrigues et al. (2008a) found eggs during the months when the adults swarm, with the highest mean being recorded in July, with nine eggs per female. Crocker et al. (1999) studied the reproductive period of Phyllophaga hirtiventris (Horn, 
1887), P. rubiginosa (LeConte, 1856), P. congrua (LeConte, 1856), and $P$. crassissima (Blanchard, 1850) and found means of $15.6 ; 8.4 ; 7.07$; and 4.4 eggs per female, respectively.

Eggs, obtained after forming $G$. borelli pairs in the laboratory, are whitish and elliptic-shaped, measuring $2.30 \times 1.60$ $\mathrm{mm}(\mathrm{n}=90)$. During the embryonic development period eggs increased in size to $3.00 \times 2.70 \mathrm{~mm}(\mathrm{n}=70)$, acquiring a rounded shape. This change in the egg size occurred between the sixth and tenth day after oviposition.

Bedford (1976) studied the biology of Scapanes australis (Boisduval, 1832) (Scarabaeidae, Dynastinae) and observed that freshly-laid eggs are elliptic in shape, measuring on average $5.18 \mathrm{~mm}$ in length and $3.14 \mathrm{~mm}$ in width. During embryonic development eggs increased in size assuming a rounded shape, with an average length of $5.20 \mathrm{~mm}$ and an average width of $4.40 \mathrm{~mm}$. Ratcliffe \& Morón (2005) studied morphological and biological aspects of Megasoma actaeon (L., 1758) (Scarabaeidae, Dynastinae) and observed an increase in the egg size of this specie a few days after oviposition.

In the plastic containers eggs were found individualized in chambers made in the soil measuring $3.5 \times 2.75 \mathrm{~mm}$ $(\mathrm{n}=35)$, and were laid in groups of two in chambers measuring $1.0 \times 1.0 \mathrm{~cm}$ on average $(\mathrm{n}=16)$. Rodrigues et al. (2010b) found L. dorsalis eggs laid individually in soil chambers measuring $1.9 \times 1.6 \mathrm{~mm}$.

Geniates borelli females brought from the field oviposited an average of 13.5 eggs $(1-29)(n=84)$ in the laboratory. Out of $535 \mathrm{G}$. borelli eggs obtained in the laboratory 414 hatched, representing a viability of $77.4 \%$. However, this value was lower than the egg viability obtained for $P$. cuyabana (88.4\%), according to Oliveira et al. (1996).

The embryonic period of $G$. borelli was 17.9 days, longer than the durations of 13.8 days for P. cuyabana (Oliveira et al. 1996), 13.2 for A testaceipennis (Rodrigues et al. 2008a), and 15.5 days for L. dorsalis (Rodrigues et al. 2010b).

The first larval instar lasted 37.6 days, the second lasted 49.7 days, and the third lasted 74 days (Table I). For L. dorsalis durations of the first, second and third instars were 32.4; 38.9; and 52.7 days, respectively (Rodrigues et al. 2010b), while for P. cuyabana durations were $26.9 ; 34.4$; and 80.8 days for the first, second, and third instars, respectively (Oliveira et al. 1996).

Table I. Duration (mean $\pm \mathrm{SE}$ ) and survival of stages from Geniates borelli Camerano in the laboratory $\left(26 \pm 1^{\circ} \mathrm{C}, 12\right.$-hour photophase).

\begin{tabular}{lcccc}
\hline \multicolumn{1}{c}{ Stage } & N & Duration (days) & Range (days) & Survival (\%) \\
\hline Egg & 535 & $17.9 \pm 0.14$ & $11-27$ & 77.4 \\
$1^{\text {st }}$ instar & 414 & $37.6 \pm 1.10$ & $22-67$ & 60.1 \\
$2^{\text {nd }}$ instar & 249 & $49.7 \pm 1.50$ & $31-86$ & 72.3 \\
$3^{\text {rd }}$ instar & 180 & $74.0 \pm 1.60$ & $50-109$ & 72.8 \\
Prepupae & 131 & $65.9 \pm 2.60$ & $32-111$ & 74.0 \\
Larvae & 97 & $205.1 \pm 5.41$ & $188-285$ & 23.4 \\
Pupae & 97 & $18.5 \pm 4.96$ & $08-30$ & 50.5 \\
Adult & 49 & $31.2 \pm 2.55$ & $09-43$ & 93.5 \\
Egg to adult & 49 & $315.8 \pm 6.44$ & $275-359$ & 9.2 \\
\hline
\end{tabular}

The head capsule width for the first instar was $1.95 \mathrm{~mm}$ (1.70-2.1), $3.3 \mathrm{~mm}(3.1-4.2)$ for the second instar, and 5.2 $\mathrm{mm}(4.9-5.8)$ for the third instar, with a 1.67 growth rate. The head capsule width of $L$. dorsalis was $1.0 \mathrm{~mm}$ for the first instar, $1.8 \mathrm{~mm}$ for the second, and $2.8 \mathrm{~mm}$ for the third (Rodrigues et al. 2010b). Therefore, G. borelli larvae are larger than $L$. dorsalis.

When the larvae of $G$. borelli reach the prepupal stage they assumed a yellowish color. During that period, they made a pupal chamber consisting of soil, measuring $34.7 \mathrm{~mm} \times$ $15.2 \mathrm{~mm}(\mathrm{n}=15)$ internally, in the bottom of the plastic container where they were reared. Such behavior has also been observed by Rodrigues et al. (2008a) in A. testaceipennis. The prepupal stage lasted 65.9 days, while the pupal stage lasted 18.5 days (Table I). The prepupal and pupal stages of L. dorsalis lasted 130.7 and 23.5 days, respectively (Rodrigues et al. 2010b). The larval duration including the prepupal stage of $G$. borelli lasted 205.1 days on average (Table I). The larval duration of $A$. testaceipennis lasted 114.7 days (Rodrigues et al. 2008a).

The adult longevity of $G$. borelli was 31.2 days (Table I). Males showed a mean longevity of 28.5 days $(9-39)(n=18)$ while females showed a mean longevity of 35.4 days (10$43)(n=31)$. Adults can be sexed by observing the tarsomeres of the first pair of legs, which are expanded in males. Jameson (2008) did a review of the Microchilus Blanchard (Rutelinae, Geniatini) and Villatoro (2002) in Triazogeniates Ohaus (Rutelinae, Geniatini), both, found that some males are differentiated from females by observation this characteristic.

Geniates borelli longevity is similar to the value observed in P. cuyabana (32.9 days, Oliveira et al. 1996) but longer than the value of 14.1 days found for $A$. testaceipennis (Rodrigues et al. 2008a).

The cycle from egg to adult in G. borelli lasted 315.8 days (Table I). Anomala testaceipennis completed its biological cycle in 139.4 days, while L. dorsalis lasted 273.5 days on average (Rodrigues et al. 2008a, 2010b).

\section{ACKNOWLEDGMENTS}

We thank the Fundação de Apoio ao Desenvolvimento do Ensino, Ciência e Tecnologia do Estado de Mato Grosso do Sul (FUNDECT) for financial support.

\section{REFERENCES}

Bedford, G. O. 1976. Observations on the biology and ecology of Oryctes rhinoceros and Scapanes australis (Coleoptera: Scarabaeidae: Dynastinae): Pests of coconut palms in Melanesia. Journal of the Australian Entomological Society 15: 241-251.

Crocker, R. L.; W. T. Nailon Junior; J. H. Matis \& R. E. Woodruff. 1999. Temporal pattern of ovipositional readiness in spring species of Phyllophaga (Coleoptera: Scarabaeidae: Melolonthinae) in North Central Texas. Annals of the Entomological Society of America 92: 47-52.

Freitas, F. A.; T. V. Zanuncio; M. C. Lacerda \& J. C. Zanuncio. 2002. Fauna de coleoptera coletada com armadilhas luminosas em plantio de Eucalyptus grandis em Santa Bárbara, Minas Gerais. Revista Árvore 26: $505-511$

Revista Brasileira de Entomologia 56(3): 315-318, setembro, 2012 
Gómez, B.; F. J. Villalobos; L. Ruiz \& A. E. Castro. 1999. Observaciones sobre la biologia de melolontidos (Coleoptera: Scarabaeoidea) en una localidad de Los Altos de Chiapas, México. Acta Zoológica Mexicana (nueva serie) 78: 173-177.

Jameson, M. L. 2008. Review of the genus Microchilus Blanchard (Coleoptera: Scarabaeidae: Rutelinae: Geniatini). Insecta Mundi 25: $1-14$.

Morón, M A. 2004. Melolontídeos edafícolas, p. 133-166. In: Salvadori, J. R.; C. J. Ávila \& M. T. B. Silva (Ed.). Pragas de Solo no Brasil. Passo Fundo: Embrapa-CNPT; Dourados: Embrapa-CPAO; Cruz Alta: Fundacep Fecotrigo, 544 p.

Oliveira, C. M.; M. A. Morón \& M. R. Frizzas. 2007. First record of Phyllophaga sp aff. capillata (Coleoptera: Melolonthidae) as a soybean pest in the Brazilian "Cerrado". Florida Entomologist 90: 772-775.

Oliveira, C. M.; M. A. Morón \& M. R. Frizzas. 2008. Aegopsis bolboceridus (Coleoptera: Melolonthidae): An important pest on vegetables and corn in Central Brazil. Florida Entomologist 91: 324-327.

Oliveira, L. J.; B. Santos; J. R. P. Parra; M. L. B. Amaral \& D. C. Magri. 1996. Ciclo biológico de Phyllophaga cuyabana (Moser) (Scarabaeidae: Melolonthinae). Anais da Sociedade Entomológica do Brasil 25: 431437.

Oliveira, L. J. \& M. A. Garcia. 2003. Flight, feeding and reproductive behavior of Phyllophaga cuyabana (Moser) (Coleotera: Melolonthidae) adults. Pesquisa Agropecuária Brasileira 38: 179-186.

Parra, J. R. P. \& M. L. Haddad. 1989. Determinação do número de instares de insetos. Piracicaba: Fundação de Estudos Agrários Luiz de Queiroz 49 p.

Ratcliffe, B. C. \& M. A. Morón. 2005. Larval descriptions of eight species of Megasoma Kirby (Coleoptera: Scarabaeidae: Dynastinae) with a key for identification and notes on biology. Coleopterists Bulletin 59: 91126.
Rodrigues, S. R.; G. A. L. Nogueira; R. R. Echeverria \& V. S. Oliveira. 2010a. Aspectos biológicos de Cyclocephala verticalis Burmeister (Coleooptera: Scarabaeidae). Neotropical Entomology 39: 15-18.

Rodrigues, S. R.; A. Puker \& E. F. Tiago. 2010b. Aspectos biológicos de Leucothyreus dorsalis Blanchard (Coleoptera, Scarabaeidae, Rutelinae). Revista Brasileira de Entomologia 54: 431-435.

Rodrigues, S. R.; A. Puker; A. R. Abot; C. L. Barbosa; S. Ide \& G. V. Coutinho. 2008a. Ocorrência e aspectos biológicos de Anomala testaceipennis Blanchard (Coleoptera, Scarabaeidae). Revista Brasileira de Entomologia 52: 68-71.

Rodrigues, S. R.; C. L. Barbosa; A. Puker; A. R. Abot \& S. Ide. 2008 b. Occurrence, biology and behavior of Liogenys fuscus Blanchard (Insecta, Coleoptera, Scarabaeidae) in Aquidauana, Mato Grosso do Sul, Brazil. Revista Brasileira de Entomologia 52: 637-640.

Salvadori, J. R. \& M. T. B. Silva. 2004. Coró-do-trigo, p.211-232. In: Salvadori, J. R.; C. J. Ávila \& M. T. B. Silva (Ed.). Pragas de Solo no Brasil. Passo Fundo: Embrapa-CNPT; Dourados: Embrapa-CPAO; Cruz Alta: Fundacep Fecotrigo, 544 p.

Santos, V. \& C. J. Ávila. 2009. Aspectos biológicos e comportamentais de Liogenys suturalis Blanchard (Coleoptera: Melolonthidae) no Mato Grosso do Sul. Neotropical Entomology 38: 734-740.

Santos, V. \& C. J. Ávila. 2007. Aspectos bioecológicos de Cyclocephala forsteri Endrodi, 1963 (Coleoptera: Melolonthidae) no estado do Mato Grosso do Sul. Revista de Agricultura 82: 298-303.

Silva, M. T. B. \& J. R. Salvadori. 2004. Coró-das-pastagens, p.191-210. In: Salvadori, J. R.; C. J. Ávila \& M. T. B. Silva (Ed.). Pragas de Solo no Brasil. Passo Fundo: Embrapa-CNPT; Dourados: Embrapa-CPAO; Cruz Alta: Fundacep Fecotrigo, 544 p.

Villatoro, K. 2002. Revision of the Neotropical genus Trizogeniates Ohaus (Coleoptera: Scarabaeidae: Rutelinae: Geniatini). Entomotropica 17: 225-294.

Received 26/11/2010; accepted 27/6/2012

Editor: Paulo Roberto Valle da Silva Pereira 